\title{
歯列弓長の前方成長に対する永久中切歯の歯軸傾斜 ならびにその位置移動の関与に関する経年的研究
}

\author{
佐々 竜三 \\ 東京医科歯科大学小児歯科学教室（指導 : 山下 浩教授） \\ （昭和46年10月15日受付）
}

\begin{abstract}
A longitudinal study of the interrelationship between the growth changes of the arch length and that of the axial inclination of the permanent central incisors and their position
\end{abstract}

\author{
Ryuji Sasa
}

Department of Pedodontics, School of Dentistry, Tokyo Medical and Dental University

(Director: Prof. Hiroshi Yamashita)

\begin{abstract}
要旨： 3 歳 5 カ月から 11 歳 2 カ月にいたる日本人小児男子 23 名，女子 22 名合計 45 名から経年的に得た側貌 頭部X線規格写真および硬石敦歯列模型を使って，歯列弓長の 発育的変化に対して 永久中切歯歯軸の発育的 変化および歯の位置的変化がどのように関与し, 永久切歯配列の調整機構にどのような 役割を果しているか を知ることを目的として，歯列弓長の発育的変化，歯軸の発育的変化および歯の位置的変化についての相互 関係を検討したところ次の結果を得た。

1. 永久中切歯歯軸の発育的変化の様相は，上下顎とも 4 つの発育型に類別することができる。

2. 歯列弓前方部の歯列弓長が発育増加する傾向にあるものは，1）先行乳中切歯と後継永久中切歯の歯軸 角度差が大きく，2）永久中切歯歯軸角度が増加する発育型を示し，3）後継永久中切歯はその先行乳中切歯 の位置よりも前方へ萠出し，4）永久中切歯の前方移動が大きいものである。

3. 永久中切歯歯軸の発育型と歯の位置的変化との関連については，1）永久中切歯歯軸の発育型としてそ の角度が増大するものは, 後継永久中切歯の萠出位置が先行乳中切歯の萠出位置より前方へ位置する傾向が あり，2）永久中切歯萠出期から歯根完成期にかけて, 永久中切歯歯軸の発育型としてその角度が減少するも のは，永久中切歯の前方移動が大きい傾向にあることが挙げられる。
\end{abstract}

\section{緒言}

歯列の発育的変化の過程で, 乳歯より 歯冠近遠 心幅径が大きい永久切歯が, どのような調整機構 によって歯列弓上に正しく配列するかはきわめて 興味あることであり，前歯部の不正咬合の成立過 程, またはその予測といった 臨床的観点からも重
要な問題である。

現在, これらの機構に関与していると思われる 要因には, 歯槽部の成長, 乳歯と永久歯の歯軸傾 斜の違い, 乳歯と永久歯の歯冠近遠心幅径の大き さの差などが挙げられている。

これらのうちで, 永久中切歯歯軸傾斜について は, Schaeffer ${ }^{4)}$, Higley $^{5)}$, 飯塚 ${ }^{6)}$, 大西ら ${ }^{7)}$ の報告 
があり，上下顎永久中切歯の歯軸は，成長発育に 伴い唇側への傾斜度を増すと述べている。

また歯槽部の成長を評価するものとしての歯列 弓の発育的変化については Moorrees ${ }^{1)}$, Baume $^{2)}$, 望月 ${ }^{3)}$ など従来数多くの報告があり，いずれも切 歯交換時に乳犬歯間幅および 歯列弓前方部の歯列 弓長が著しく増大することを述べている。しかし 歯列弓の発育的変化は，歯槽部の成長のみでなく 歯軸の発育的変化や歯の位置的変化によって影響 を受けることが考えられる。

ところで，これら歯列弓の発育的変化および歯 軸傾斜に関する報告は，その各々について調査， 観察したものであって, 歯列弓の発育的変化と歯 軸傾斜の変化および歯の位置的変化との関連性を 述べた報告は未だ見当らない。

そこで著者は, 歯列弓前方部の 発育とくに歯列 弓長の変化に歯軸傾斜の発育的変化と 歯の位置的 変化が, どのように関与し, 永久切歯配列の調整 機構にどのような役割を果しているかを知ること を目的として, 同一個体について乳歯列から混合 歯列にいたる経年的観察を行ない，歯列弓と歯軸 傾斜の発育的変化抢よび 歯の位置的変化につい て, これらの相互関係を検討し, 興味ある知見を 得たので報告する。

\section{資料および計測方法}

\section{1. 資 料}

資料採得の対象は，東京医科歯科大学小児歯科 外来に来院した日本人小児で，乳歯列期に咬合関 係ならびに歯列弓が正常と思われた約 100 名で, 観察期間は 3 歳 5 力月から 11 歳 2 力月に抢よぶほ ぼ 7 年間である。

このうち経年的観察の過程で 計測上支障をきた すと思われる歯冠崩壊, 乳犬歯の早期喼失, 過度 の over-jet, over-bite などが起らなかった男子23 名，女子22名合計 45 名を観察資料とした。

計測資料は，これら小児より得た側貌頭部 X線 規格写真および同時期に同一個体から得た硬石高 歯列模型である。このうち計測は, 各個体につい て乳歯列期, すなわち第 2 乳臼歯の萠出が完了し
た時期, 永久中切歯萠出前期, 寸なわち 永久中切 歯の口腔方向一の萠出移動が進行し, 先行乳中切 歯歯根のおよそ $1 / 2 \sim 3 / 4$ が吸収されている時期, 永 久中切歯萠出期, 寸なわち 永久中切歯が口腔内に 萠出を開始した時期，永久中切歯歯根完成期，す なわちセフアロ上で永久中切歯が歯根を完成した と思われる時期の 4 つの時期を設定し，この時期 に相当する資料を選んで計測を行なった。

\section{2. 計測方法}

1）模型上の計測部位および計測方法

模型上の計測部位および計測方法は，研究者に よって種々な方法が試みられているが，著者は， 歯列弓前方部の 歯列弓長（以後歯列弓長という） として, 上下顎両側乳中切歯または永久中切歯の 唇面接線の中点から, 両側乳犬歯咬頭頂間を結ん だ線への垂線の長さを用いた（図 1)。

A L
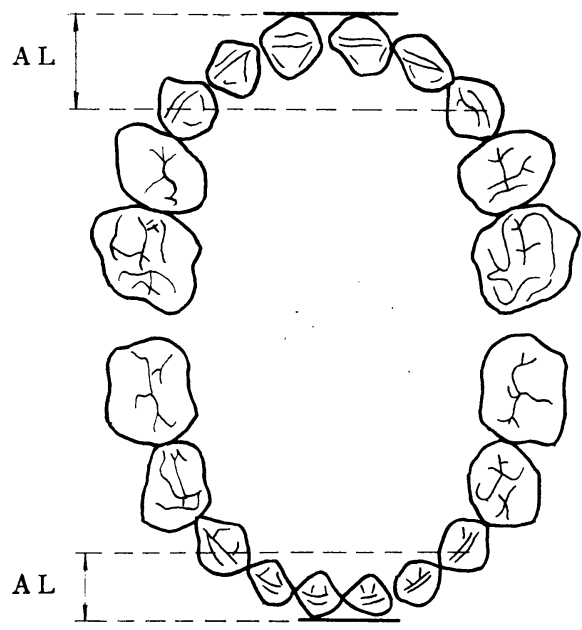

図 1 計測部位

A L : 歯列弓前方部の歯列弓長

計測にあったっては，大坪8)の Basal Arch 計 測器に ${ }^{1} / 20 \mathrm{~mm}$ の副尺を付けて改良したものを用 いた。

2）側貌頭部 X線規格写真上の 計測点および計 測方法

側貌頭部X線規格写真上における歯軸角度の 計測には，上澦では $\mathrm{S}-\mathrm{N}$ 平面に対する上顎乳中切 歯および永久中切歯歯軸の交叉角，下顎では下顎 

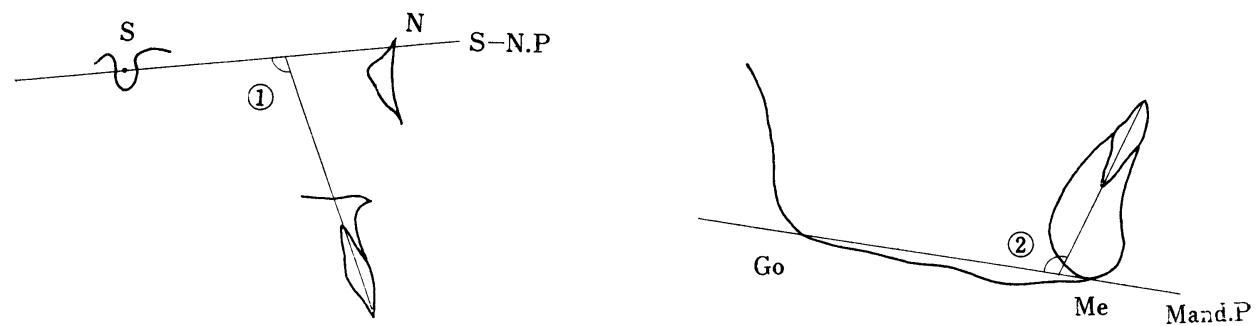

図 2 角度的計測項目

(1): 上顎中切歯歯軸角度 (2): 下顎中切歯歯軸角度

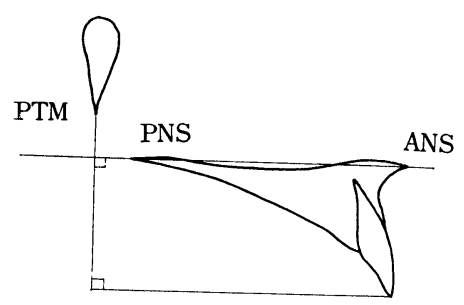

(1)

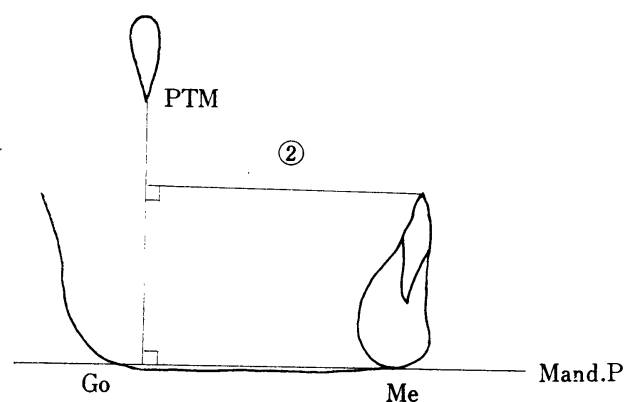

$\mathrm{Me}$

図 3 距離的計測項目

(1)：上䫟中切歯から PTM までの距離

乳歯

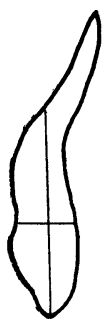

根未完成歯

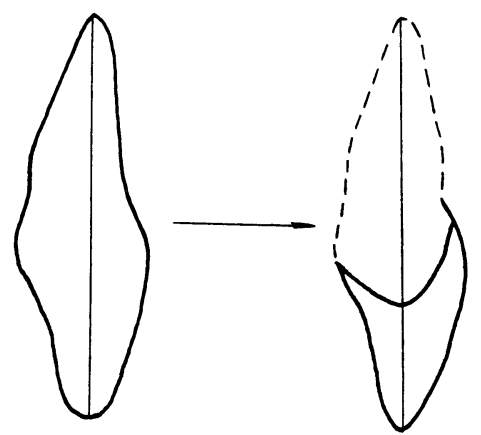

図 4 歯軸の設定

下縁平面に対する下頡乳中切歯㧍よび 永久中切歯 歯軸の交叉角を用いた。また歯の前方への移動変 化を知るために, Ptm を基準点として各発育段階 における乳中切歯および永久中切歯までの距離を 測定した（図 $2 ， 3$ ）。計測は上下顎とも右側の乳 中切歯あるいは永久中切歯を用いた。

3）歯軸の設定

永久中切歯歯軸の決定は, 切縁の中央から歯根
(2) : 下顎中切歯から PTM までの距離

尖端にいたる直線を用い，根未完成歯の場合は， 同一歯の歯根完成時における中切歯像をセファロ 上で透写し，その透写図を根未完成歯の歯冠像に 重ね合わせて当該歯の歯軸線を設定した。

また乳中切歯の歯軸は，乳歯と永久歯では形態 上種々な相違があるため, 切縁の中央と唇舌両歯 頸部間の中点とを結ぶ線を用いた（図 4)。

\section{研 究結果}

\section{1. 歯軸の変化および歯の前方移動}

1）永久中切歯歯軸の発育的变化

45名の各個体の上下顎永久中切歯の 歯軸角度に ついてそれらが示す増令的変化を観察すると，図 5 抢よび図 6 に示すように，上下顎とも 4 つの型 に類別することができた。

すなわち，上顎においては，I 型は乳歯列期か ら増令に伴なって歯軸角度の減少がみられるもの で，この型を示すものが18例，II型は増令に伴な って歯軸角度がほとんど 変化しないものでこれが 4 例, III型は増令に伴なって歯軸角度が増大する 


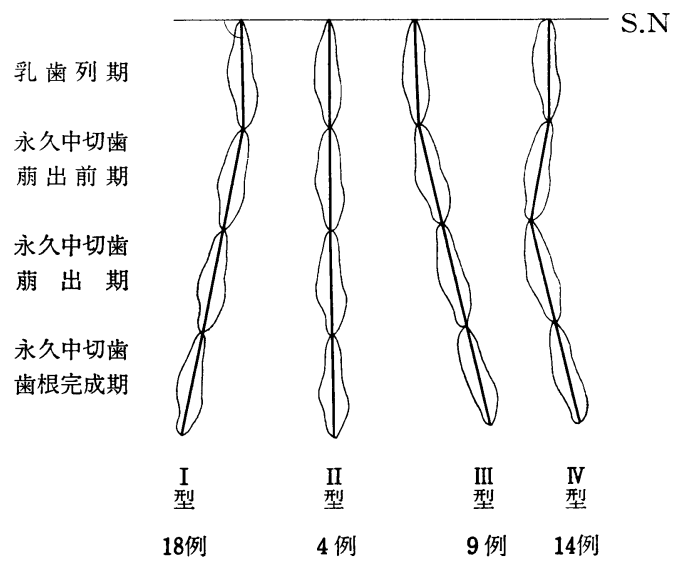

図 5 上顎永久中切歯の歯軸の発育型

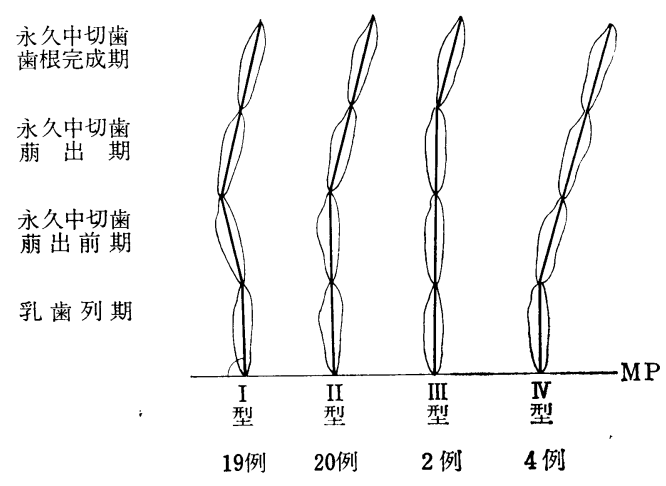

図 6 下澦永久中切歯の歯軸の発育型
ものでこれが 9 例, IV型は乳歯列期から 永久中切 歯萠出前期まで歯軸角度の減少があり。永久中切 歯が萠出するとともに，それが増大するもので, これが14例認められた。 また，下顎においては，I 型は乳歯列期から 永久 中切歯萠出前期 まで歯軸角度の 減少があり, 口 腔内萠出以降はそれが増大するもので，この型を 示寸ものが19例， II型は乳歯列期から 永久中切歯 萠出前期まで歯軸角度に変化がなく， 口腔内萠出 以降はそれが増大するもので，これが20例，而型 は乳歯列期から 永久中切歯が口腔内に萠出をみる まで歯軸角度に変化がなく, その後増大するもの で, これが 2 例, IV型は増令とともに漸次歯軸角 度の増大がみられるもので，これが 4 例認められ た。

これらの 4 つの型の各発育段階における 歯軸角 度の実測值の平均值を算出すると, 表 1 に示した ようになる。

2）乳中切歯の歯軸角度と 永久中切歯の歯軸角 度の相違

本研究では, 乳歯列期における 乳中切歯の歯軸 角度と同一個体の永久中切歯萠出期に計測した永 久中切歯の歯軸角度とを比較検討した。

上顎では，45例すべてについて 永久中切歯歯軸 角度の方が乳中切歯のそれよりも大きく, そのう ち角度差が 10 度以上のものが 29 例 (64.4\%)，10度

表 1 永久中切歯歯軸の発育型別の各発育段階における歯軸角度の平均值（度）

\begin{tabular}{|c|c|c|c|c|c|c|c|c|c|c|}
\hline \multirow{2}{*}{\multicolumn{3}{|c|}{$\begin{array}{c}\text { 発育段階 } \\
\text { 発育型 } \\
\text { 例数 } \\
\end{array}$}} & \multicolumn{2}{|c|}{ 乳 歯 列 期 } & \multicolumn{2}{|c|}{ 永久中切歯萠出前期 } & \multicolumn{2}{|c|}{ 永久中切歯萠出期 } & \multicolumn{2}{|c|}{ 永久中切歯歯根完成期 } \\
\hline & & & 平均值 & S.D & 平均值 & S.D & 平均值 & S.D & 平均值 & S.D \\
\hline 卡 & I & 18 & 115.8 & 7.78 & 110.6 & 7.78 & 105.1 & 5.33 & 102.2 & 5.13 \\
\hline 等 & II & 4 & 110.1 & 3.35 & 109.8 & 2.55 & 110.3 & 4.30 & 109.7 & 3.68 \\
\hline 中 & III & 9 & 101.2 & 8.33 & 103.0 & 8.11 & 109.5 & 5.51 & 112.7 & 4.81 \\
\hline $\begin{array}{l}\text { 切 } \\
\text { 歯 }\end{array}$ & IV & 14 & 105.4 & 7.77 & 98.3 & 7.50 & 107.2 & 5.59 & 109.9 & 5.54 \\
\hline $\begin{array}{l}\text { 下 } \\
\text { 顎 }\end{array}$ & I & 19 & 84.9 & 4.54 & 80.7 & 4.55 & 94.9 & 7.30 & 98.4 & 7.76 \\
\hline 永 & II & 20 & 84.4 & 5.04 & 84.5 & 5.73 & 94.6 & 4.47 & 97.8 & 3.55 \\
\hline 中 & III & 2 & 80.7 & 9.54 & 80.0 & 9.19 & 80.0 & 8.48 & 91.0 & 0.00 \\
\hline 切 & IV & 4 & 81.8 & 4.21 & 89.3 & 4.51 & 96.8 & 2.95 & 99.2 & 1.75 \\
\hline
\end{tabular}


表 2 乳中切歯と永久中切歯の歯軸角度差

\begin{tabular}{|c|c|c|c|c|}
\hline \multirow{3}{*}{$\begin{array}{l}\text { 上 } \\
\text { 顎 }\end{array}$} & & \multicolumn{2}{|c|}{ 永久中切歯>乳中切歯 } & 永久中切歯＜乳中切歯 \\
\hline & $\begin{array}{l}\text { 角 } \\
\text { 度 } \\
\text { 差 }\end{array}$ & 27.5-10.5 & $\begin{array}{r}8.0-0.5 \\
\text { 度 }\end{array}$ & \\
\hline & $\begin{array}{l}\text { 症 } \\
\text { 列 } \\
\text { 数 }\end{array}$ & $\begin{array}{c}29 \text { 例 } \\
(64.4 \%)\end{array}$ & $\begin{array}{c}16 \text { 例 } \\
(35.6 \%)\end{array}$ & \\
\hline 下 & 度 & $\begin{array}{r}18.0-10.0 \\
\text { 度 }\end{array}$ & $8.5-0.5$ & $7.0-2.0$ \\
\hline 䪽 & $\begin{array}{l}\text { 症 } \\
\text { 列 } \\
\text { 数 }\end{array}$ & $\begin{array}{c}23 \text { 例 } \\
(51.1 \%)\end{array}$ & $\begin{array}{c}16 \text { 例 } \\
(35.5 \%)\end{array}$ & $\begin{array}{c}6 \text { 例 } \\
(13.4 \%)\end{array}$ \\
\hline
\end{tabular}

\begin{tabular}{|c|c|c|c|}
\hline & & 上 顎 & 下 顎 \\
\hline \multirow[t]{2}{*}{ 乳中切歯歯軸角度 } & 平均值 & $91.9^{\circ}$ & $86.5^{\circ}$ \\
\hline & $\mathrm{SD}$ & 6.26 & 6.47 \\
\hline \multirow{2}{*}{ 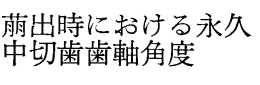 } & 平均値 & $106.2^{\circ}$ & $94.1^{\circ}$ \\
\hline & SD & 5.48 & 6.63 \\
\hline
\end{tabular}

以下のものが16例 $(35.6 \%)$ 認められた。

一方下顎では，45例中39例が 永久中切歯歯軸角 度の方が大きく，そうち角度差が 10度以上のもの が23例 (51.1\%)，10 度以下のものが 16例（35.5 \%) 認められた。また下䫟においては，上顎では みられなかった乳中切歯の歯軸角度の方が永久中 切歯のそれよりも大きいものが 6 例 (13.4\%) 認 められた (表 2 )。

3. 永久中切歯の前方移動

永久市切歯が増令とともに示す前方移動を観察 するため, 各発育段階における永久中切歯の位置 的変化を検索した。

乳歯列期における乳中切歯の位置と, 同一個体 の永久中切歯萠出期における 永久中切歯の位置と の関係は, 表 3 に示寸ように, 上䪽では差が 10 $\mathrm{mm}$ 以上のもの, 寸なわち永久中切歯の萠出位置 が乳中切歯より $10 \mathrm{~mm}$ 以上前方に位置ししてい たものが 1 例認められた。また, 差がなかったも の, すなわち乳中切歯の位置と永久中切歯の萠出 位置が同じであったものが 7 例みられ，残りの 37 例は, $10 \mathrm{~mm}$ 以内の範用で永久中切歯が乳中切歯 より前方に位置していた。

また下顎ではその差が $10 \mathrm{~mm}$ 以上のものは認め られず, 差が認められなかったものが 5 例, 残り
表 3 乳中切歯の萠出位置と永久中切歯の萠出 位置の差

\begin{tabular}{|c|c|c|c|c|c|}
\hline & 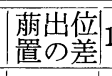 & $10 \mathrm{~mm}$ 以上 & $\begin{array}{c}10 \mathrm{~mm} \text { 未満 } \\
5 \mathrm{~mm} \text { 以上 }\end{array}$ & $\begin{array}{l}5 \mathrm{~mm} \text { 未満 } \\
0 \mathrm{~mm} \text { 以上 }\end{array}$ & 不変化 \\
\hline \multirow{2}{*}{$\begin{array}{l}\text { 上 } \\
\text { 顎 }\end{array}$} & 症例数 & $\begin{array}{c}1 \text { 例 } \\
(2.0 \%)\end{array}$ & $\begin{array}{c}9 \text { 例 } \\
(20.0 \%)\end{array}$ & $\begin{array}{c}28 \text { 例 } \\
(62.2 \%)\end{array}$ & $\begin{array}{c}7 \text { 例 } \\
(15.5 \%)\end{array}$ \\
\hline & \multicolumn{5}{|c|}{ 萠出位置の差の平均 $2.66 \mathrm{~mm} \mathrm{St}$} \\
\hline \multirow{2}{*}{$\begin{array}{l}\text { 下 } \\
\text { 萼頁 }\end{array}$} & 症例数 & 0 & $\begin{array}{c}12 \text { 例 } \\
(26.5 \%)\end{array}$ & $\begin{array}{c}28 \text { 例 } \\
(62.2 \%)\end{array}$ & $\begin{array}{c}5 \text { 例 } \\
(11.1 \%)\end{array}$ \\
\hline & & 萠出位置 & の平均 & $\mathrm{mm}$ & 2.42 \\
\hline
\end{tabular}

表 4 永久中切歯の前方移動

\begin{tabular}{|c|c|c|c|c|c|}
\hline & 移動量 & $10 \mathrm{~mm}$ 以上 & $\begin{array}{c}10 \mathrm{~mm} \text { 末満 } \\
5 \mathrm{~mm} \text { 以上 }\end{array}$ & $\begin{array}{l}5 \mathrm{~mm} \text { 末満 } \\
0 \mathrm{~mm} \text { 以上 }\end{array}$ & 不変化 \\
\hline \multirow{2}{*}{$\begin{array}{l}\text { 上 } \\
\text { 顎 }\end{array}$} & 症例数 & $\begin{array}{c}2 \text { 例 } \\
(4.4 \%)\end{array}$ & $\begin{array}{c}15 \text { 例 } \\
(33.3 \%)\end{array}$ & $\begin{array}{c}28 \text { 例 } \\
(62.2 \%)\end{array}$ & 0 \\
\hline & \multicolumn{5}{|c|}{ 移動量平均 $4.27 \mathrm{~mm} \mathrm{SI}$} \\
\hline \multirow{2}{*}{$\begin{array}{l}\text { 下 } \\
\text { 顎 }\end{array}$} & 症例数 & 0 & $\begin{array}{c}5 \text { 例 } \\
(11.1 \%)\end{array}$ & $\begin{array}{c}37 \text { 例 } \\
(82.2 \%)\end{array}$ & $\begin{array}{c}3 \text { 例 } \\
(6.6 \%)\end{array}$ \\
\hline & \multicolumn{5}{|c|}{ 移動量平均 $2.36 \mathrm{~mm}$ SD 1.76} \\
\hline
\end{tabular}

の 40 例は $10 \mathrm{~mm}$ 以内の範囲で永久中切歯の萠出位 置が乳中切歯より前方に位置していた。

表 4 は, つぎの発育段階すなわち 永久中切歯が 口腔内に萠出を開始した時期から 歯根が完成する までの永久中切歯の前方移動量を示したものであ る。

上顎においては, 永久中切歯が $10 \mathrm{~mm}$ 以上前方 移動を行なったものが 2 例, 残りはすべて $10 \mathrm{~mm}$ 以内の範囲で前方移動を示していた。

また下顎では，10mm 以上前方移動をしたもの は認められず，前方移動がまったくなかったもの が 3 例認められた。

\section{2. 歯列弓長の変化}

表 5 は, 乳歯列期から 永久中切歯萠出期にかけ ての歯列弓長の変化を示している。

上顎では, $1 \mathrm{~mm}$ 以上増加したものが 25 例(55.5 $\%)$, 増加量 $1 \mathrm{~mm}$ 未満のものが 8 例 $(17.7 \%)$, 変化のなかったものが 12 例 (26.6\%) 認められ た。一方下顎では， $1 \mathrm{~mm}$ 以上増加したものが 23 例 $(51.1 \%)$, 増加量が $1 \mathrm{~mm}$ 末満のものが 10 例 $(22.2 \%)$, 変化のなかったものが10例 $(22.2 \%)$, 
表 5 乳歯列期から永久中切歯萠出期にかけて の歯列弓前方部の歯列弓長の増加例およ び不変化, 減少例

\begin{tabular}{|c|c|c|c|c|c|}
\hline & & 増 & 加 & 不 変 化 & 減＼cjkstart少 \\
\hline \multirow{2}{*}{ 上 } & \multirow{2}{*}{ 例数 } & $1 \mathrm{~mm}$ 以上 & $1 \mathrm{~mm}$ 末満 & & \\
\hline & & $\begin{array}{c}25 \text { 例 } \\
(55.5 \%)\end{array}$ & $\begin{array}{c}8 \text { 例 } \\
(17.7 \%)\end{array}$ & $\begin{array}{c}12 \text { 例 } \\
(26.6 \%)\end{array}$ & 0 \\
\hline 顎 & \multicolumn{5}{|c|}{ 平均増加量 $1.40 \mathrm{~mm}$ SD 1.19} \\
\hline \multirow{2}{*}{ 下 } & \multirow{2}{*}{ 例数 } & $1 \mathrm{~mm}$ 以上 & $1 \mathrm{~mm}$ 末満 & & \\
\hline & & $\begin{array}{c}23 \text { 例 } \\
(51.1 \%)\end{array}$ & $\begin{array}{c}10 \text { 例 } \\
(22.2 \%)\end{array}$ & $\begin{array}{c}10 \text { 例 } \\
(22.2 \%)\end{array}$ & $\begin{array}{c}2 \text { 例 } \\
(2.2 \%)\end{array}$ \\
\hline 顎 & \multicolumn{5}{|c|}{ 平均増加量 $1.06 \mathrm{~mm}$ SD 0.98} \\
\hline
\end{tabular}

表 6 永久中切歯萠出期から歯根完成期にかけ ての歯列弓前方部の歯列弓長の増加例お よび不変化，減少例

\begin{tabular}{|c|c|c|c|c|c|}
\hline & & 増 & 加 & 不変 化 & 減 少 \\
\hline \multirow{2}{*}{ 上 } & \multirow{2}{*}{ 例数 } & $1 \mathrm{~mm}$ 以上 & $1 \mathrm{~mm}$ 末満 & & \\
\hline & & $\begin{array}{c}37 \text { 例 } \\
(82.2 \%)\end{array}$ & $\begin{array}{c}8 \text { 例 } \\
(17.7 \%)\end{array}$ & 0 & 0 \\
\hline 影 & \multicolumn{5}{|c|}{ 平均増加量 $1.72 \mathrm{~mm}$ SD 1.00} \\
\hline \multirow{2}{*}{ 下 } & \multirow{2}{*}{ 例数 } & $1 \mathrm{~mm}$ 以上 & $1 \mathrm{~mm}$ 末満 & & \\
\hline & & $\begin{array}{c}19 \text { 例 } \\
(42.2 \%)\end{array}$ & $\begin{array}{c}20 \text { 例 } \\
(44.4 \%)\end{array}$ & $\begin{array}{c}6 \text { 例 } \\
(13.3 \%)\end{array}$ & 0 \\
\hline 顎 & \multicolumn{5}{|c|}{ 平均増加量 $0.95 \mathrm{~mm}$} \\
\hline
\end{tabular}

減少したものが 2 例（4.4\%）認められた。

表 6 は，永久中切歯萠出期から 歯根完成期にか けてこの歯列弓長の変化を示したものである。

上顎ではすべての症例で増加が認められた。下 顎では $1 \mathrm{~mm}$ 以上増加があったものが19例（42.2 $\%$ ), 増加量が $1 \mathrm{~mm}$ 末満のものが20例 (44.4\%), 変化がなかったものが 6 例 $(13.3 \%)$ 認められ た。

乳歯列期から 永久中切歯萠出期にかけての歯列 弓長の増加量の平均值は, 上顎 $1.40 \mathrm{~mm}$, 下顎 1.06 $\mathrm{mm}$ ，また 永久中切歯萠出期から歯根完成期にか けての増加量の平均值は上顎 $1.72 \mathrm{~mm}$, 下頢 0.95 $\mathrm{mm}$ で，これらの発育段階における歯列弓長の成 長増加量を上下顎で 比較すると, 両段階とも上䪽
表 7 症例数別にみた歯列弓長の変化と歯軸角 度差との関係

上顎

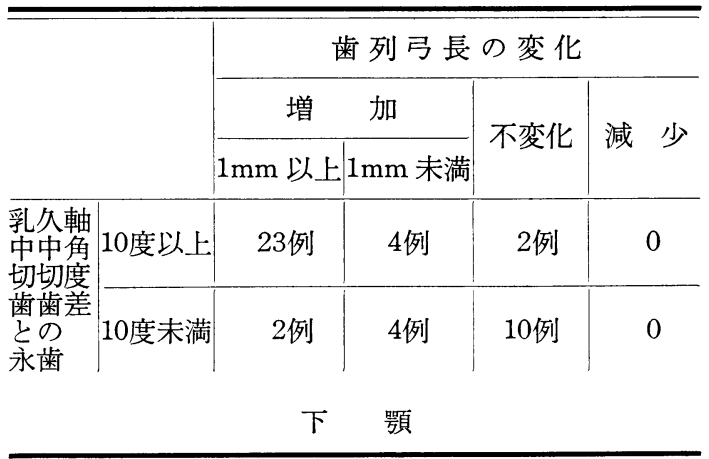

歯列弓長の変化

\begin{tabular}{|c|c|c|c|c|c|}
\hline & & 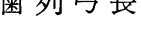 & 変 & \\
\hline & & 増 & 加 & \multirow{2}{*}{ 不変化 } & \multirow{2}{*}{ 減 少 } \\
\hline & & \multicolumn{2}{|c|}{$1 \mathrm{~mm}$ 以上 $1 \mathrm{~mm}$ 末満 } & & \\
\hline \multirow{3}{*}{$\begin{array}{l}\text { 乳久軸 } \\
\text { 中中角 } \\
\text { 切切度 } \\
\text { 歯歯 } \\
\text { との } \\
\text { 永歯 }\end{array}$} & 10 度以上 & 20例 & 1例 & 1例 & 0 \\
\hline & 10 度未満 & 1例 & 8例 & 6例 & 2例 \\
\hline & 0 度末満 & 2例 & 1例 & 3例 & 0 \\
\hline
\end{tabular}

の方が大きかった。

3. 歯列弓長の変化と, 乳中切歯と永久中切歯 の歯軸角度差, 永久中切歯の歯軸の発育型, 乳中切歯と永久中切歯の萠出位置の差およ び永久中切歯の前方移動との関係

1）歯列弓長の変化と, 乳中切歯と 永久中切歯 の歯軸角度差との関係

歯列弓長が増加する個体，減少する個体と乳中 切歯および 永久中切歯の歯軸角度差が 大きい個 体，小さい個体との関連を各個体数別に調查した ものは表 7 に示してある。すなわち，歯列弓長が 増加しているものには乳中切歯と 永久中切歯の歯 軸角度差の大きい個体が多く，逆に，歯列弓長が 不変化, 減少しているものには乳中切歯と永久中 切歯の歯軸角度差が小さい個体が多いことが示さ れている。

そこでさらに, 各個体について歯列弓長の変化 に対し乳中切歯と永久中切歯の歯軸角度差がどの ように関係しているかを検討するために，歯列弓 長の増減量と，乳中切歯と 永久中切歯の歯軸角度 


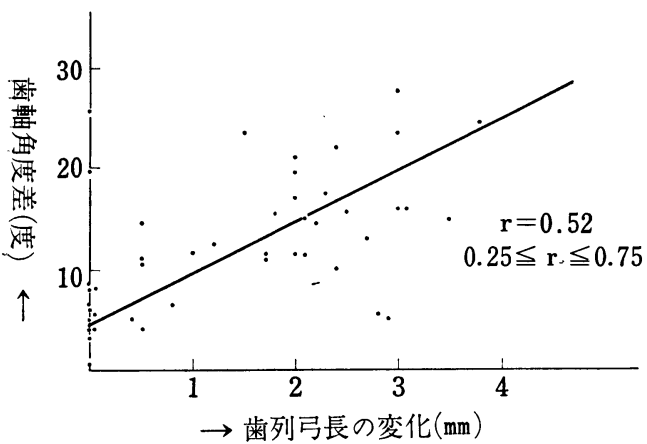

図 7 歯列弓長の変化と乳中切歯および永久中 切歯の歯軸角度差との相関 (上枵)

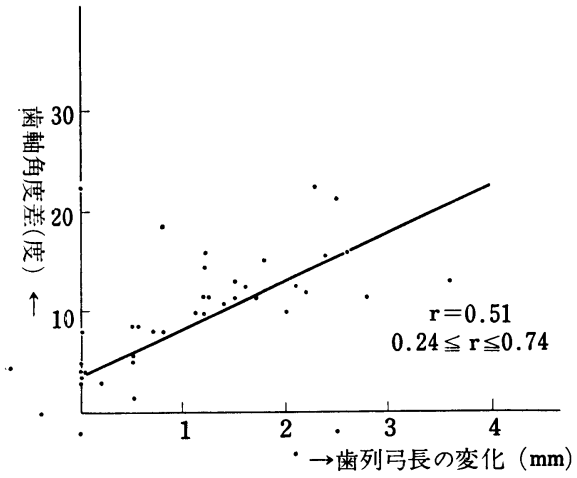

図 8 歯列弓長の変化と乳中切歯および 永久中切歯の歯軸角度差との相関 (下顎)

差の大小との間の相関関係を求めた。その結果， 相関係数が上顎で 0.52 ，下顎 0.51 と有意の比較的 高い相関が認められた（図 7，8）。すなわち，乳 中切歯と永久中切歯の歯軸角度差の大きいものほ ど歯列弓長も大きくなる傾向にあることがわか った。

2）歯列弓長の変化と, 永久中切歯歯軸の 発育 型との関係

歯列弓長の増加を示す個体，あるいは減少を示 寸個体が，永久中切歯歯軸の 発育型（I 型 II 型III 型IV型）の何型に多く属しているかを調査した結 果は表 8 に示してある。

すなわち，上顎では歯軸角度の 増大を示す III型 およびIV型の個体は, 乳歯列期から 永久中切歯萠 出期にかけての歯列弓長が増加を示すものに多 く，逆に歯軸角度の減少を示す I 型の 個体は，乳
表 8 症例数別にみた歯列户長の変化と歯軸の 発育型との関係

\begin{tabular}{|c|c|c|c|c|c|}
\hline & & & \multicolumn{3}{|c|}{ 歯列弓長の変化 } \\
\hline & & & $\begin{array}{l}\text { 増 加 } \\
(\text { (例) }\end{array}$ & $\begin{array}{l}\text { 不変化 } \\
(\text { 例) }\end{array}$ & $\begin{array}{c}\text { 減 少 } \\
\text { )例） }\end{array}$ \\
\hline \multirow{8}{*}{$\begin{array}{l}\text { 永 } \\
\text { 久 } \\
\text { 中 } \\
\text { 切 } \\
\text { 歯 } \\
\text { 歯 } \\
\text { 軸 } \\
\text { の } \\
\text { 発 } \\
\text { 育 } \\
\text { 型 }\end{array}$} & \multirow{4}{*}{\begin{tabular}{|l} 
乳 \\
歯萠 \\
列 \\
期出 \\
1 期
\end{tabular}} & I & 12 & 6 & 0 \\
\hline & & II & 3 & 1 & 0 \\
\hline & & III & 7 & 2 & 0 \\
\hline & & IV & 11 & 3 & 0 \\
\hline & \multirow{4}{*}{$\begin{array}{l}\text { 萠 } \\
\text { 出歯 } \\
\text { 根 } \\
\text { 期完 } \\
\text { 成 } \\
\text { 期 }\end{array}$} & I & 18 & 0 & 0 \\
\hline & & II & 4 & 0 & 0 \\
\hline & & III & 9 & 0 & 0 \\
\hline & & IV & 14 & 0 & 0 \\
\hline
\end{tabular}

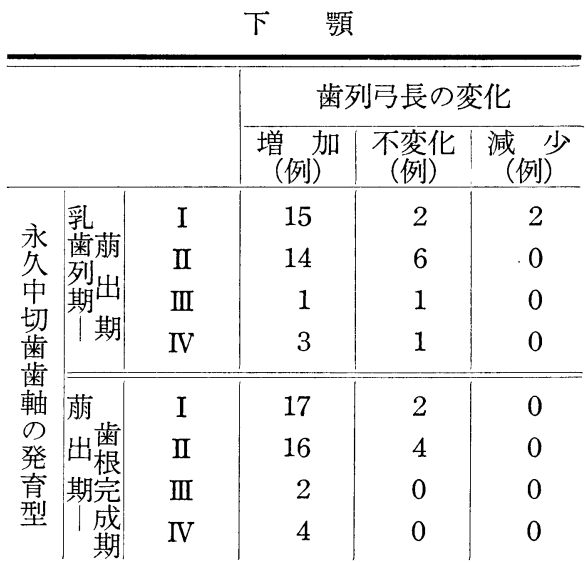

歯列期から永久中切歯萠出期にかけての歯列弓長 が不変化を示すものに多かった。この関連を確め るために，歯列弓長が増加するもの，減少するも のと，歯軸角度が増大するもの（III, IV型)，減少 するもの（I 型）との関係について $\chi^{2}$ 検定を行 なった結果有意の差が認められた。すなわぢ永 久中切歯歯軸角度が増大する型の方が，乳歯列期 から永久中切歯萠出期にかけての歯列弓長が大き くなる傾向にあることを知った。

また，永久中切歯萠出期から 歯根完成期にかけ ては，発育型に関係なくすべての個体に歯列弓長 の増加がみられた。

一方下顎では, 表 8 に示されているように，乳 歯列期から永久中切歯にかけて 歯列弓長に増加を 


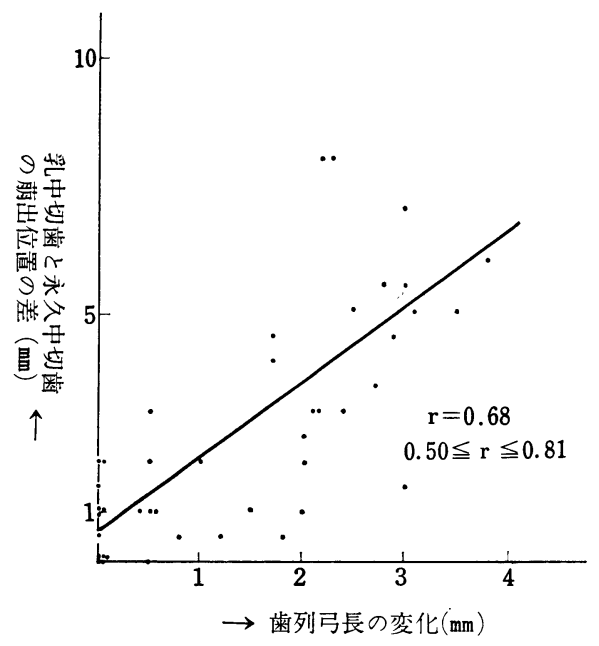

図 9 歯列尸長の変化と乳中切歯および 永久中切歯の萠出位置の差との相 関（上顎）

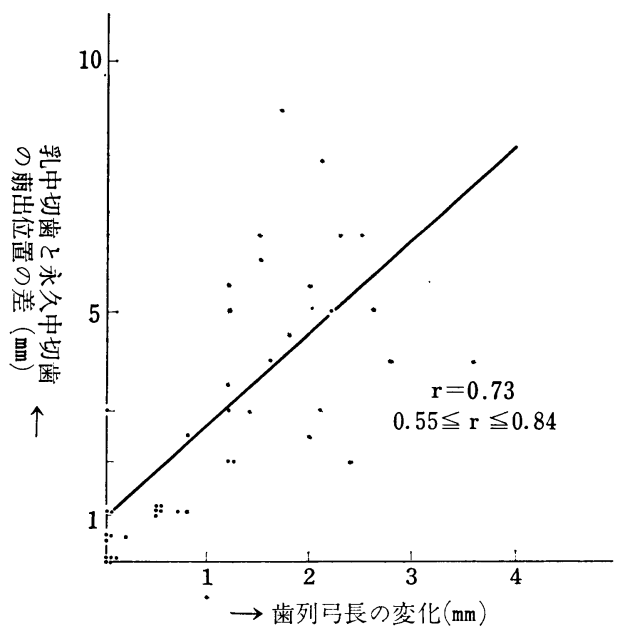

図 10 歯列弓長の 変化と乳中切歯およ び永久中切歯の萠出位置の差と の相関(下顎)

示していたものは，I 型が15例，II が14例，III型 が 1 例，IV型が 3 例であった。また歯列弓長に不 変化，あるいは減少を示していいたものは，I 型 が 4 例, II 型が 6 例, III型が 1 例, IV型が 1 例で あった。下顎は歯軸角度の発育傾向が類似してい るI 型および川型の発育型をもっ 個体が多いこと から，上顎のように歯軸角度の増減と歯列弓長の 増減との関係について $\chi^{2}$ 検定を行ならことがで きなかった。
また，永久中切歯萠出期かから 歯根完成期にか けては，I 型の 2 例, II 型の 4 例が歯列弓長に不 変化を示した以外は他のすべての 個体に歯列弓長 の増加がみられた。

3）歯列弓長の変化と, 乳中切歯と 永久中切歯 の萠出位置の差との関係

歯列弓長の変化に対して, 乳歯列期における乳 中切歯の位置と永久中切歯萠出期に打ける永久中. 切歯の萠出位置との差がどのように関与している かを知るために，各個体について 歯列弓長の増減 量と乳中切歯と永久中切歯の萠出位置の差の変化 量との間の相関係数を求めた。その結果，相関係 数が上顎で 0.68 , 下顎で 0.73 と有意のきわめて高 い相関があることが認められた（図 $9 ， 10 ） 。$

すなわち, 永久中切歯が乳中切歯の位置に対し てより前方に萠出したものほど，歯列弓長も大き くなる傾向にあることがわかった。

4）歯列弓長の変化と, 永久中切歯前方移動と の関係

歯列弓長の変化に対して，永久中切歯萠出期か ら歯根完成期にかけての永久中切歯の前方移動が どのように関与しているかを知るために，歯列弓 長の増減量と永久中切歯の前方移動量との相関係 数を求めた。その結果，上頢で 0.70 , 下顎で 0.67 と有意のきわめて高い相関があることが認められ，

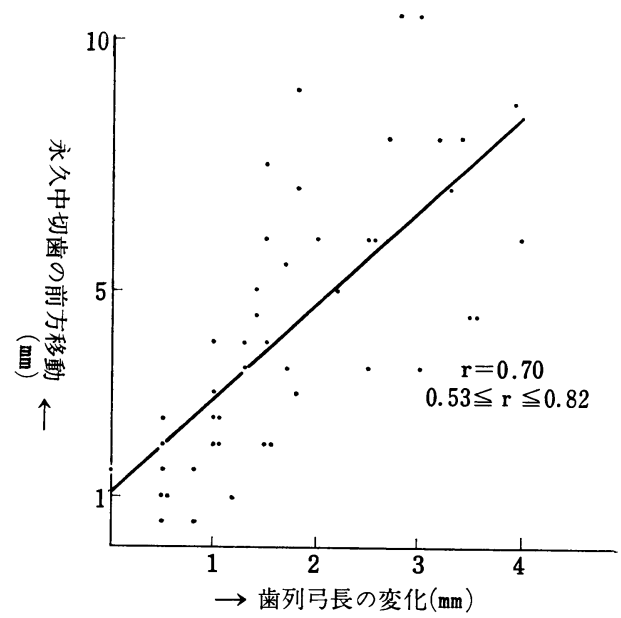

図 11 歯列弓長の 変化と 永久中切歯の 前方程動との相関 (上顎) 


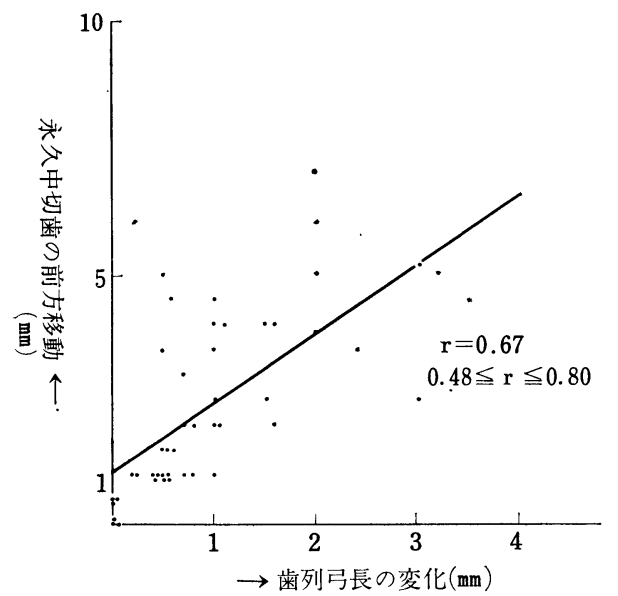

図 12 歯列污長の 变化と 永久中切歯前 方移動との相関 (下顎)

た（図11，12）。

すなわち, 永久中切歯の前方移動が大きいもの ほど，歯列弓長も大きくなる傾向にあることがわ かった。

5）乳中切歯と永久久中切歯の 萠出位置の 差 と, 永久中切歯歯軸の発育型との関係

乳中切歯と永久中切歯の萠出位置の差と, 永久 中切歯歯軸の発育型とがどのように関係している かを知るために, 乳中切歯と永久中切歯の萠出位 置の差の変化量と 歯軸角度の 増減との関係を $\chi^{2}$ 検定を使って検討した。

その結果上䕘では, 乳中切歯と永久中切歯の萠 出位置の差の変化量についてみると, 歯軸角度が 増大するIII型IV型と減少する I 型との間に有意の 差が認められた。

すなおち，I 型のものより，III型およびIV型の ものの方が永久中切歯の萠出位置が 乳中切歯の位 置に対してより前方にある傾向が認められた。

一方下顎では, 永久中切歯歯軸の 発育型が類似 しているため上顎におけるような関係を調べるこ とができなかった。

6) 永久中切歯の前方移動と 永久中切歯歯軸の 発育型との関係

永久中切歯の前方移動と 永久中切歯歯軸の発育 型とがどどのように関与しているかを知るため
に, その移動量と歯軸角度の増減との関係を $\chi^{2}$ 検 定を使って検討した。

その結果上顎では, 歯軸角度が増大する III型IV 型ならびに歯軸角度が減少するI型と, 永久中切歯 の前方移動量との間では有意の差が認められた。

すなわち，III型および IV型のものより，I 型の ものの方が永久中切歯萠出期から 歯根完成期にか けて永久中切歯の前方への移動が大きい傾向にあ ることが認められた。

一方下顎では, 永久中切歯歯軸の 発育型がこの 時期には45例中43例のものが増大しており，また 減少を示すものがないことから，上顎におけるよ らな関係は検討できなかった。

\section{考察}

乳歯列期から混合歯列期に至る間における歯列 弓長の発育的変化と永久中切歯歯軸の変化との関 係，およびそれに関連すると思われる諸因子との 関連を検討した結果から次のような考察を試み た。

\section{1. 永久中切歯歯軸傾斜について}

永久中切歯歯軸傾斜についての従来の研究は, 欧米白人についてMargolis ${ }^{9)}$, Noyes $ら^{10)}$, Spiedel $ら^{11)}$, Schaeffer ${ }^{4)}$, Higley $^{5)}$, Markus $^{12)} ら か ゙ ， ま$ た日本人については, 粥川 ${ }^{13,14)}$, 吉原 ${ }^{15)}$, 大西7) らの報告がある。これらは，いずれも横断的資料 を用いて, 顔面頭蓋の発育に伴う永久中切歯の歯 軸の変化を調査したものであり, Margolis ${ }^{9)}$, Spiedel ${ }^{11)}$ ，および Markus ${ }^{12)}$ らは下頇中切歯歯軸 と下顎下縁平面との交叉角について報告してい る。

Margolis" は，下顎中切歯が “lean-back”す なわち後方へ傾斜しているものは下顎下縁平面と の交叉角は小さく，逆に“lean-forward”すな わち前方へ傾斜していくるものは下顎下縁平面と の交叉角は大きくなる傾向があることを述べてい る。

また, Markus ${ }^{12)}$ は, 成人について正常咬合で は，下顎中切歯歯軸と下縁平面との交叉角は，ほ ぼ垂直に近いことを指摘している。 
Higley ${ }^{5)}$ は，上下顎永久中切歯の歯軸と S-N 平 面，下顎下縁平面との交叉角を検討し，これらの 歯軸角度はいずれも5 歳から 8 歳にいたるまで著 しい増大があることを報告している。

これらの報告をみると，上下頡永久中切歯は増 令に伴なって唇側傾斜度を増すことが一致した見 解である。

著者の得た研究結果のうち，永久中切歯につい て, 萠出以後の歯軸角度の変化を観察すると, 上 瀕では，45例中18例は歯軸角度の減少を示してい た。この歯軸角度の減少については従来の報告に はなかったことであり，これはそれらの報告が歯 軸角度を平均成長的に 観察をしたものであるのに 反し，本研究では個成長的に 観察を試みた結果に よるものと思われる。

また，未萠出の永久中切歯歯軸の 変化について は，著者の検討結果からみると，上䫑においては 歯軸角度が減少したものが 45例中 32 例と圧倒的に 多く，下顎においても同様であった。未萠出永久 中切歯歯軸角度について平均成長的な観察を行な った飯塚 ${ }^{6)}$ の報告も同様な結果を示している。

これは, 永久中切歯未萠出の時期では, 先行乳 歯が口蓋側あるいは舌側に 位置しているために， 永久中切歯の歯冠部の前方移動が抑制されて，そ の歯軸角度が減少するのではないかと思われる。

\section{2. 乳中切歯と永久中切歯の歯軸角度の相運に} วいて

同一個体の乳中切歯と永久中切歯の 歯軸角度を 比較した結果については，表 2 に示したように上 顎ではすべての症例，下顎では45例中 39 例が永久 中切歯歯軸角度の方が乳中切歯のそれよりも大き かったことが認められた。

Moyers ${ }^{17)}$ も通常乳前歯は咬合平面に対して垂 直に近い軸傾斜を示し，そのため 永久前歯にくら べて直立しており，その inter-incisla angle も大 きいことを報告している。

しかし，本研究結果でもみられるように，下顎 において, 乳中切歯の歯軸角度の方が永久中切歯 の歯軸角度より大きかった症例が 6 例みられてい る。この乳中切歯の歯軸角度の方が大きい原因の
表 9 乳中切歯歯軸角度の方が, 永久中切歯歯 軸角度より大きかつた 6 例と，その歯列 弓長の変化

\begin{tabular}{|c|c|c|c|}
\hline 症 例 & $\begin{array}{l}\text { 乳中切歯 } \\
\text { 歯軸角度 }\end{array}$ & $\begin{array}{l}\text { 永久中切歯 } \\
\text { 歯軸角度 }\end{array}$ & $\begin{array}{l}\text { 歯列弓長の } \\
\text { 増減 }\end{array}$ \\
\hline 2 & $90.0^{\text {度 }}$ & $86.0^{\text {度 }}$ & $\begin{array}{l}(\mathrm{mm}) \\
+2.1\end{array}$ \\
\hline 8 & 80.0 & 74.0 & 0 \\
\hline 39 & 90.0 & 88.0 & +2.0 \\
\hline 76 & 99.5 & 86.0 & 0 \\
\hline 77 & 99.0 & 92.0 & 0 \\
\hline 82 & 95.5 & 93.5 & 0 \\
\hline
\end{tabular}

一つとしては，日本人の下顎骨では，下頡隆起が 比較的大きいため顎骨内の 後継永久中切歯が正常 な位置よりも舌側方向に存在し，そのまま萠出し たのではないかということが考えられる。

乳中切歯と永久中切歯の歯軸角度差と 歯列弓長 の変化との関連性については，乳中切歯と永久中 切歯の歯軸角度差の大きいものほど 歯列弓長も大 きくなる傾向にあることが認められた。このこ とから考えると永久中切歯歯軸角度が 乳中切歯の それよりも小さかった下顎の 6 例は歯列弓長が増 加することは考えられない。しかし表 9 に示され ているように，個体成長的に 観察すると6 例のう ち 2 例は歯列弓長が増加していることが認められ た。これは，歯列弓長の増加に関与する 因子が乳 中切歯と永久中切歯の 歯軸角度差だけでなく, 他 の因子すなわち永久中切歯の前方移動も大きな因 子の一つであることを示唆しているものと考えら れる。

\section{3. 永久中切歯の前方移動について}

日本人顔面頭蓋の成長についての坂本 ${ }^{18)}$ の報告 によれば，上下顎永久中切歯は顔面頭蓋の成長に 伴なって前方変位が著しく，とくに 5 歳頃から 7 歳頃にかけて著明であり，女子の方が男子ょり 前方変位が著しいことを指摘し，また Higley ${ }^{5)}$, 飯塚 ${ }^{6)}$ ら 前歯交換時に著明な永久中切歯の唇側 傾斜とともに前方移動があることを報告してい る。

Brodie $^{30)}$ ，坂本 ${ }^{16)}$ らは側貌頭部 X線規格写真を 用いての顔面頭蓋の成長発育の研究において，上 
顎骨後方限界を表わす Ptm の前後方向への 発育 的変化は比較的少ないことを指摘している。そこ で本研究では, 側貌頭部 X 線規格写真上の Ptm を基準として, 永久中切歯の前方移動について検 討した。その結果, 表 3 および表 4 に示されてい るように, 永久中切歯萠出期における 永久中切歯 の萠出位置が乳歯列期における乳中切歯の萠出位 置よりも上顎で平均 $2.66 \mathrm{~mm}$, 下顎で平均 $2.84 \mathrm{~mm}$ 前方へ萠出していた。また，永久中切歯が口腔内 に萠出を開始した時期から歯根が完成するまでの 間に, 永久中切歯は上顎で平均 $4.27 \mathrm{~mm}$, 下顎で 平均 $2.36 \mathrm{~mm}$ の前方移動が認められた。

この永久中切歯の前方移動と歯列弓長の変化と の関係は, 両者の間に高い相関があることは図 9，10，11，12 に示した通りである。すなわち， 永久中切歯の萠出位置 が 乳中切歯の位置に対し てより前方に萠出したものほど，歯列弓長も大 きくなる傾向があり，また永久中切歯の前方移動 が大きいものほど歯列弓長も大きくなる傾向があ る。

このことは, 上顡において永久中切歯の前方移 動が $10 \mathrm{~mm}$ 以上みられた症例（症例 $12 ， 77,92$ ) は歯列弓長にも著明な増加がみられ，前方移動の 少なかった症例（症例 $8,16,25,47,58,66$, 69）は歯列弓長に変化がなかったことからも裹付 けされる(表 10)。このような個体がみられたこと は，歯列弓長の発育に関与する因子の一つとし

表 10 永久中切歯の前方移動が大きい個体と 小さい個体の歯列弓長の変化

\begin{tabular}{c|c|c}
\hline 症 例 & $\begin{array}{c}\text { 永久中切歯前方移動 } \\
(\mathrm{mm})\end{array}$ & $\begin{array}{c}\text { 歯列弓長の変化 } \\
(\mathrm{mm})\end{array}$ \\
\hline 12 & 10.5 & 2.8 \\
77 & 10.5 & 3.0 \\
92 & 11.5 & 2.0 \\
8 & 0 & 0 \\
16 & 0 & 0 \\
25 & 0 & 0 \\
47 & 0 & 0 \\
58 & 0 & 0 \\
66 & 0 & 0 \\
69 & 0 & 0
\end{tabular}

て，歯の前方移動も大きな 因子の一つになってい ることが理解できる。

\section{4. 歯列弓長の変化について}

歯列の成長変化に関する研究については従来多 く報告されている。すなわち Baume ${ }^{2)}$, Moor$\mathrm{rees}^{1)}$, 望月 ${ }^{3)}$, その他 ${ }^{18-29)}$ のものがある. これら のうち, Lewis ら ${ }^{19)}$, Sillman $^{23,24,29)}$, Baume ${ }^{2)}$, Clinch $^{21)}$, Moorrees ${ }^{1)}$, 小野ら ${ }^{28)} ら$, 総体的に 歯列弓の成長変化を観察し，また Lewis ${ }^{25)}$ Sill$\operatorname{man}^{23,24,29)}$, 望月ら ${ }^{3)}$ は歯列の個成長に 関する研 究を行なっている。

これらの報告を見るとそのいずれもが歯列弓長 は乳歯列期にはほとんど変化しないが，永久前歯 萠出期に著明な増加がみられることを指摘してい る。また, Cohen ${ }^{201}$ は, 歯列弓におけるもっとも 大きな前方への成長は犬歯より前方の部位で行な われ，その成長の最も大きな時期は，永久歯が萠 出する時であると述べている。

永久中切歯萠出前から萠出後にかけての 歯列弓 長の発育的変化については, 本研究で資料とした 症例の多くは増加を示したが増加を示さなかつた 症例もあった。すなわち表 5 に示すように, 上顎 12例，下澦10例に変化が見られず，また下顎 2 例 ではかえって減少していることが認められなた。 この減少を示した症例 1 と症例 34 は, 下頡永久中 切歯萠出に僅かな叢生を起こしていること，永久 中切歯の 前方移動が極めて少ないことなどから， 減少した原因がこれらによるものと思われる。 永久中切歯萠出期から 歯根完成期にかけての歯 列弓長の変化は, 下顎において変化のなかったも の 6 例を除いてすべて増大が認められた。Gold-

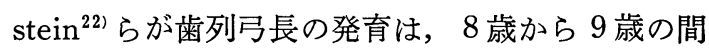
が最も大きいことを指摘しているよらに，本研究 でも永久中切歯萠出期から歯根完成期にかけて は, 中切歯の前方移動と歯軸傾斜の増大によると 思われる歯列弓長の増加が認められた。

\section{5. 歯列弓長の変化と, 乳中切歯と永久中切歯 の歯軸角度の差, 永久中切雪歯軸の発育型, 乳中切雪と永久中切雪の萠出位置の差およ び永久中切歯の前方移動との関係について}


歯列弓長の発育的変化および 永久中切歯歯軸角 度の変化についての研究は, 従来多くの研究者に よって報告されているが，この両者の関連性を検 討した報告は見当らない。

本研究で，これら相互間の関連性を検討した結 果, 歯列弓長の発育的変化に関与する因子とし て, 乳中切歯と永久中切歯の歯軸角度差, 永久中 切歯歯軸の発育型, 乳中切歯と永久中切歯の萠出 位置の差および 永久中切歯の前方移動があること を確め得た。また, それら諸因子の歯列弓長の発 育的変化に対する 関与の様相も知った。すなわち 一般的傾向として, 乳歯列期から永久中切歯萠出 期にかけて，乳中切歯と永久中切歯の歯軸角度の 差が大きく, 永久中切歯歯軸の発育型が増大の 型 をとり, 永久中切歯の萠出位置が乳中切歯の位置 に比べて前方に 位置しているものは, その時期の 歯列弓長に増加がみられ, また永久中切歯萠出期 から 歯根完成期にかけて, 永久中切歯歯軸の発育 型が増大の型をとり, 永久中切歯の前方移動の大 きいものは, その時期の歯列弓長が増加する傾向 がある。

しかし，個成長的に 観察すること，この一般的 傾向がすべての個体に必ずしもあてはまるもので はないことがいくつかの症例について観察され た。

表 11 症例 47 おび85の歯列弓長の変化に対 する諸因子の様相

\begin{tabular}{|c|c|c|c|c|}
\hline 症例 & 発育型 & 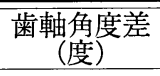 & \begin{tabular}{|c|}
$\mid \begin{array}{c}\text { 萠出位置の差 } \\
(\mathrm{mm})\end{array}$ \\
\end{tabular} & $\begin{array}{l}\text { 歯列局長の } \\
\text { 変化 }(\mathrm{mm})\end{array}$ \\
\hline 47 & III型 & 25.5 & 0 & 0 \\
\hline 85 & I 型 & 5.0 & 4.5 & 2.9 \\
\hline
\end{tabular}

表11に示されているように, 症例47は, 乳歯列 期から永久中切歯萠出期にかけて, 永久中切歯歯 軸の発育型が増大の型を示し, 乳中切歯と永久中 切歯の歯軸角度の差が大きいにもかかわらず，永 久中切歯の萠出位置が乳中切歯の位置とほとんど 変化ないため歯列弓長に増加がみられていない。 また症例 85 は, 乳歯列期から 永久中切歯萠出時期 にかけて, 永久中切歯歯軸の発育型が減少の型を
示し, 乳中切歯と永久中切歯の歯軸角度の 差が小 さいにもかかわらず, 永久中切歯が乳中切歯の位 置に対してょり前方に萠出したため歯列弓長に増 加が見られた。

このような症例がみられたことは，個体によっ て歯列弓長の変化に対する諸因子の量的，あるい は時期的な関与の仕方に違いがあり，それによっ て歯列弓長の経時的変化に差異が生じるものと考 えられる。

最後に, 永久中切歯歯軸の 発育型およびこの発 育型と永久中切歯の前方移動との関係をみると， 発育型が I 型のものは萠出時以後歯軸角度が増加 することはなく, またIII, IV型のものは決して減 少することはない。また萠出時以後の歯の前方移 動は，I 型のものの方方がIII，IV 型を示すものよ り大きいことが知られた。

このような結果に基ずいて，個体の永久中切歯 歯軸の変化および歯の前方移動を予測することが できるならば，永久中切歯の萠出時に不正咬合 （交叉咬合，過蓋咬合)の傾向を示すような 症例に 対して，その診断あるいは治療方針の 決定に有用 な補助的手段として役立つのではないかと思われ る。しかし，これについては本研究だけでは決定 的なことはないえず今後の検討が必要であろう。

\section{総括および結論}

3 歳 5 カ月から 11 歳 2 力月にいたる 日本人小児 の男子 23 名, 女子 22 名計 45 名について，それらか ら経年的に得た 側貌頭部 X 線規格写真および硬石 高歯列模型を使って, 歯列弓前方部の 歯列弓長の 発育的変化と永久中切歯歯軸の発育的変化ならで にその前方移動との関連について 検討したところ 次の結果を得た。

1. 永久中切歯歯軸の発育的変化の様相は, 上 下顎とも 4 つの発育型に 類別することができる。

2. 歯列弓前方部の歯列弓長が 発育増加する傾 向にあるものは，1）先行乳中切歯と後継永久中 切歯の歯軸角度の差が大きく，2）永久中切歯歯 軸角度が増加する発育型を示し，3）後継永久中 切歯はその 先行乳中切歯の位置よりも前方へ萠出 
し，4）永久中切歯の前方移動が大きいものであ る。

3. 永久中切歯歯軸の発育型と歯の移動との関 連については，1）永久中切歯歯軸の 発育型とし てその角度が増大するものは, 後継永久中切歯の 萠出位置が先行乳中切歯の萠出位置より前方へ位 置する傾向があり，2）永久中切歯萠出期から歯 根完成期にかけて, 永久中切歯歯軸の 発育型とし てその角度が減少するものは, 永久中切歯の前方 移動が大きい傾向にあることが挙げられる。

稿を終るに当たり，御指導ならびに御校閲下さいまし た山下浩教授に対し, また終始御助言, 御教示下さいま した小野博志助教授に対して謹んで謝意を表します。

さらに，本研究資料の採得に御協力いただいた小児歯 科学教室員諸氏に感謝致します。

\section{文献}

1) Moorrees, C. F. A.: The dentition of the growing child, Camblidge Massachusetts, 1959, Harvard University, P. 87.

2) Baume, L. J. : Physiological teeth migration and its significance for the development of occlusion, J. D. R., 29 : 123, 331, 338, 440, 1950.

3）望月清之: 歯列の成長変化に関する経年的研究, 口病誌, $32: 357,1965$.

4) Schaeffer, A.: Behavior of the axis of human incisor teeth during growth, Angle Orthod, $19: 254,1945$.

5) Higley, L. B.: Cephalometric standards for children 4 to 8 years of age, A. J. O., 40 : $51,1954$.

6）飯塚哲夫：頭部X線規格写真法による日本人小 児の顔の成長に関する研究, 口病誌, $25: 260$, 1958.

7）大西 馨：学童期における上下顎歯槽基底部と 中切歯傾斜度との関係，一頭部 X 線規格側貌写 真による経年的研究一, 日矯歯誌, $28: 12,1969$.

8）大坪淳造：模型分析のための歯列弓および Basal Arch の長径の計測器について, 日矯歯誌, $19: 159,1960$.

9) Margolis, H. I. : The axial inclination of the mandibular incisors, A. J. O. and O. S., 29 : 571, 1943.

10) Noyes, H. J., Rushing, C. H. and Sims, H. A. : The angle of axial inclination of human central incisor teeth, Angle Orthod, 8:60,
1943.

11) Speidel, J. D., Stoner, M. M. : Variation of mandibular incisor axis in adult "Normal" occlusion, A. J. O. and O. S. 30 : 536, 1944.

12) Markus, M. B. : A study of the angular relationship in the upper and lower anterior teeth, A. J. O., $36: 281,1950$.

13）粥川 浩：レントゲンセファログラムによる日 本人顮態の研究, I. ダウンズ 分析法による検 討, 日矯歯誌, $13: 6,1954$.

14）粥川 浩：レントゲンセファログラムによる日 本人顎態の研究， II.ノースウェスタン法によ る検討, 日矯歯誌, $14: 6,1955$.

15）吉原稔人：レ線による日本人の脑頭蓋および顔 面頭蓋の形態学的研究, その一, 日本人乾燥頭 蓋骨についての分析, 日矯歯誌， $14: 21,1955$.

16）坂本敏彦：日本人顔面頭蓋の成長に関する研究 -SELLA TURCICA を基準として一，日矯歯 誌, $18: 1,1959$.

17) Moyers, R. E. : Hand book of orthdontics, 2nd, Cihcago, 1963, Year Book Medical Publisher, P. 58.

18) Moorrees, C. F. A., Chadha, J. M. : Available space for the incisors during dental development-A growth study based on physiological age, Angle Orthod, $35: 12,1965$.

19) Lewis, S. T. : Observation on growth changes of the teeth and denal arches, D. Cos, $71: 480,1929$.

20) Cohen, J. J.: Growth and development of the dental arches in children, J. A D. A., 1250, 1940.

21) Clinch, L. M. : An analysis of serial models between three and eight years of age The Dent. Res, $71: 61,1951$.

22) Goldstein, M. S., Stanton, F. L. : Changes in dimensions and form of the dental arches with age, Int. J. Orthod, $21: 357,1935$.

23) Sillman, J. H. : Serial study of occlusion (Birth to ten year of age) A. J. O., 1948.

24) idem: Serial study of good occlusion from birth to 12 years of age. A. J. O., $37: 481$, 1951.

25) Lewis, S. J.: Some aspect of dental arch growth, J. A. D. A., $23: 277,1936$.

26) Foster, H. R.: An analysis of the developing dentition, J. A. D. A., 42: 376, 1951.

27) Burson, C. E. : A study of individual variation in mandibular bicanine dimension during growth, A. J. O., $38: 848,1952$.

28）小野博志, 落合靖一, 佐藤 博 : 歯列の成長変 化に関する研究, 第一報, 乳歯列の成長変化に ついて, 口病誌, $27: 361,1960$. 
29) Sillman, J. H.: Some aspect of individual dental development : Longitudinal study from birth to 25 years, A. J. O., $51: 1,1965$.
30) Brodie, A. G. : Late growth changes in the human face, Angle Orthod, 23 : 146, 1955. 